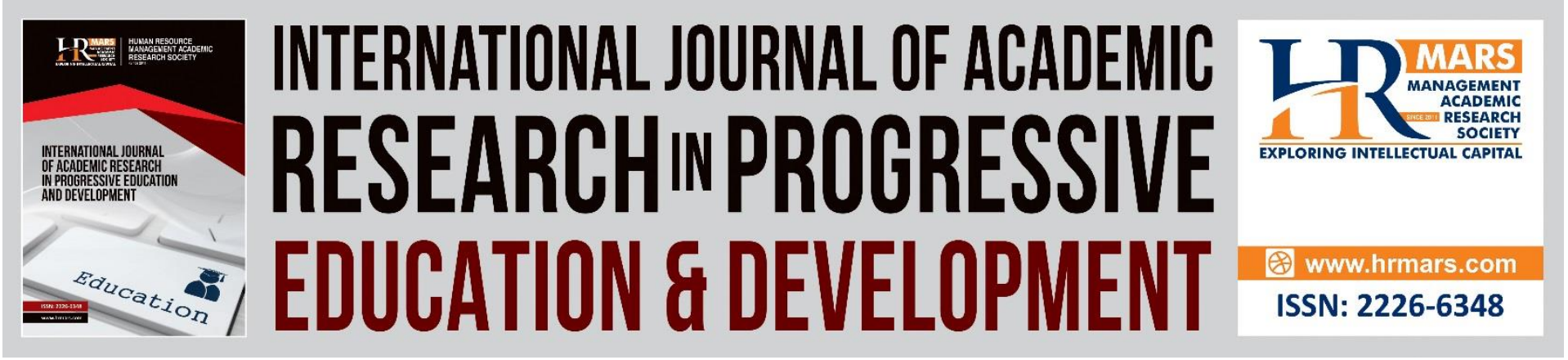

\title{
Development of Missionary Schools in Sarawak 1840-1960
}

\section{Sidek Pawi, Ramli Saadon \& Abdul Talib Mohamed Hashim}

To Link this Article: http://dx.doi.org/10.6007/IJARPED/v10-i3/11481

DOI:10.6007/IJARPED/v10-i3/11481

Received: 07 July 2021, Revised: 14 August 2021, Accepted: 30 August 2021

Published Online: 25 September 2021

In-Text Citation: (Pawi et al., 2021)

To Cite this Article: Pawi, S., Saadon, R., \& Hashim, A. T. M. (2021). Development of Missionary Schools in Sarawak 1840-1960. International Journal of Academic Research in Progressive Education and Development, 10(3), 1088-1094.

Copyright: (c) 2021 The Author(s)

Published by Human Resource Management Academic Research Society (www.hrmars.com)

This article is published under the Creative Commons Attribution (CC BY 4.0) license. Anyone may reproduce, distribute, translate and create derivative works of this article (for both commercial and non-commercial purposes), subject to full attribution to the original publication and authors. The full terms of this license may be seen at: http://creativecommons.org/licences/by/4.0/legalcode

$$
\text { Vol. 10(3) 2021, Pg. } 1088-1094
$$

Full Terms \& Conditions of access and use can be found at http://hrmars.com/index.php/pages/detail/publication-ethics 


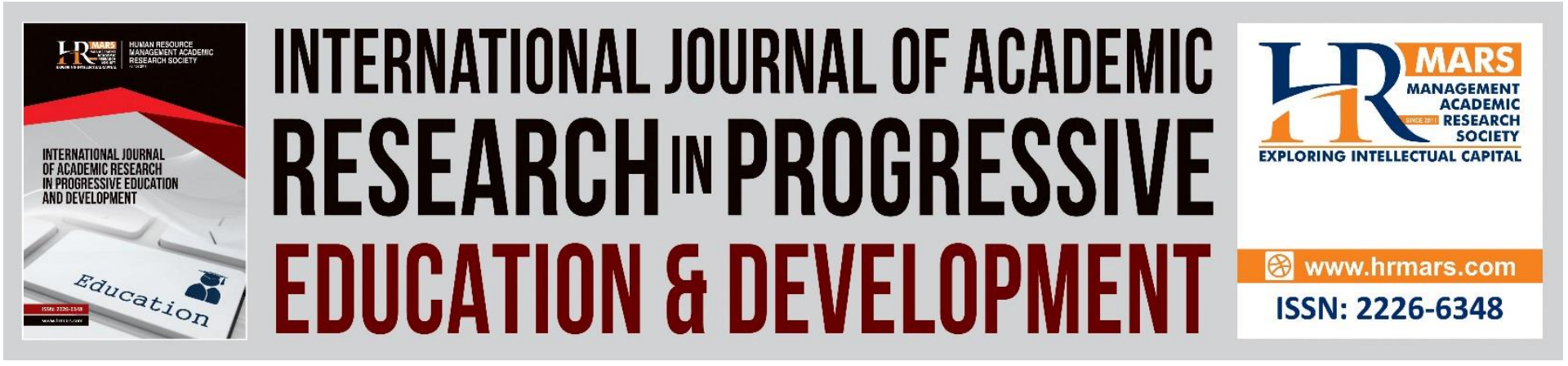

\title{
Development of Missionary Schools in Sarawak 1840-1960
}

\author{
Sidek Pawi, Ramli Saadon \& Abdul Talib Mohamed Hashim \\ Faculty of Human Sciences, Universiti Pendidikan Sultan Idris, Tanjong Malim, Perak, \\ Malaysia
}

\begin{abstract}
This study is to find out the development of missionary schools in Sarawak during the years from 1840-1960. Qualitative method is used to analyse the primary sources of various documents pertaining to the few missionary schools found in major towns around Sarawak. Among the main aspects studied are the development of basic education in the primary and secondary missionary schools in Sarawak starting from the Brooke era in the 1840s to the British Colonial Administration in the 1960s, the Church's role in thedevelopment of missionary schools in Sarawak, the administration and management of missionary schools, and the financial management of missionary schools in developing infrastructure and the edification of education in Sarawak. All the data obtained were narratived into a meaningful source of history. This study is of utmost importance to further increase our understandings in the uniqueness of missionary schools that had contributed to development of education in Sarawak.
\end{abstract}

Keywords: Education, Brooke Dynasty, British Colonial, Missionary

\section{Introduction}

Education is a very important platform in the development of a civilised society. But the acceptance of the Sarawakian native society towards education during the Brooke Administration era weren't very encouraging until the arrival of missionaries with their mission to bring 'civility' with their active Christian propagation among the local populace. James Brooke's openess enabled the missionaries to open early educational centres without any regulations or restrictions. This was due to their concept of bringing civilisation to the native people which was regarded by the misssionaries as a golden opportunity to spread Christianity via the school system. This can be seen throughout the 27 years of James Brooke's rule, he wasn't serious in anyway to provide early education to his native Sarawak subjects. This was because he did not build any government schools for the native Sarawak people. This clearly demonstrated that James Brooke adopted an open policy and did not encouraged any education for the native people (Pringle, 1970). Nevertheless, he very much encouraged and supported the establishment of schools operated by Christian missionary bodies such as by the Anglicans with the hope to eliminate the Dayak's traditional beliefs in animism such as the worshipping of spirits, souls and ghosts (Currey, 1933). Furthermore, he was also convinced that the non Muslim natives could only be made civilised by the propagation of the 
Christian religion. James Brooke had then handed over the tasks to the Christian Missionaries to provide a formal education and to convert the people of Sarawak to Christianity. This was done with the goal to discipline and change the lifestyle of the natives which was viewed as wild (Idrus, 1990). Therefore in order to achieve their mission to convert the natives to Christianity, the Brooke Dynasty had utilised various methods for the natives to receive the Christian religion on their own free will.

As for the local populace who were Muslims, James Brooke had never ever interfered or intervened in their cultures because he respected and valued the support given to him by the Sarawak Malay leaders who had helped him in obtaining Sarawak from the Malay lords (Runciman, 1960) During James Brooke's rule, traditional ecucation was available for the Muslim populace such as religious recitals at suraus and at the houses of Muslim religious teachers namely hajis and lebais. But then the condition of those 'schools' weren't so stimulating and eventually had to be handed over to private schools often ran by Christian missionaries. As a matter of fact, the attitude or the mentality of the Malays then became an important factor in determining the development of missionary schools because of the Malay views of Western education as secular and could erode traditional education along with their religious characteristics which were taught at home or at suraus. In fact after the closure of a few Malay schools occured, some missionary organizations had taken over those schools and that contributed to the increase in number of missionary schools. On the other hand, the Dayak community had a better realisation on knowledges and the job opportunities available to them within the Christian religion. (Varney, 1969). In fact the curriculum system introduced by the missionary schools then was seen as relevant with their surroundings and living culture. Under the missionary organizations, the educational system was seen as more organised and systematic. However many of the Christian educational schools at the early stages were concentrated in the interior areas and not at the coastal areas of Sarawak.

In fact throughout the whole period of the Brooke Administration era until the British Administration, the development of missionary schools were constantly given priority in the aspects of physical developments and financial fundings. Even during the post World War Two era, the intensity of the British in furthering the mission schools and intensifying their proselytizing activities among the populace of Sarawak were evident. Based on the table 1, its clearly shows that the involvement of outsiders enabled the British to provide huge funds to upgrade missionary education resulting in an increased literacy rate among the people of Sarawak (Ooi, 1996). 
Table 1: Sarawak Native Literacy Rate, 1947

\begin{tabular}{|l|l|l|l|l|l|}
\hline $\begin{array}{l}\text { Ethnic } \\
\text { Group }\end{array}$ & $\begin{array}{l}\text { Population } \\
\text { (\%) }\end{array}$ & $\begin{array}{l}\text { Illiterate } \\
\mathbf{( \% )}\end{array}$ & $\begin{array}{l}\text { Recognise } \\
\text { English } \\
\text { Alphabets } \\
\text { (Person) }\end{array}$ & $\begin{array}{l}\text { Recognise } \\
\text { Other } \\
\text { Languages } \\
\text { Alphabets } \\
\text { (Person) }\end{array}$ & $\begin{array}{l}\text { Literate } \\
\text { Population } \\
\text { (Person) }\end{array}$ \\
\hline Malay & 17.9 & 85 & 1,433 & 11,077 & 12,510 \\
\hline Melanau & 6.5 & 91 & 336 & 2,258 & 2,594 \\
\hline Iban & 34.8 & 98 & 1,062 & 2,563 & 3,625 \\
\hline Bidayuh & 7.7 & 93 & 327 & 2,153 & 2,480 \\
\hline $\begin{array}{l}\text { Other } \\
\text { Natives }\end{array}$ & 5.5 & 98 & 21 & 548 & 569 \\
\hline Total & $\mathbf{7 2 . 4}$ & & $\mathbf{3 1 , 1 7 9}$ & $\mathbf{1 8 , 5 9 9}$ & $\mathbf{2 1 , 7 7 8}$ \\
\hline
\end{tabular}

Source: Ooi, 1996, p.104

The History and Development of Education in Sarawak During The Brooke Dynasty Administration

The development of formal education in Sarawak had actually begun when James Brooke specifically invited Christian missionaries of Anglican denomination from The Society for the Propagation of the Gospel (SPG) which then landed in Kuching in 1848. On 28th June 1848, Francis Thomas McDougall and his wife Harritte together with his colleague Rev. William Bodman Wright and his wife had sailed along the Sarawak River and landed at Kuching. They then spread Christian teachings to the Second Division and then to the Fourth Division in 1920. Next, in November 1950, McDougall had visited the Bidayuhs in Quop and they were found to be keen to embrace the Anglican Christian denomination (Saunders, 1992). Other than that, Rev. Chalmers had arrived in Quop in 1858 and he opened a school which was named St. James. Rev. Chalmers mission was continued by Rev. Achhung Ah Luk and as a result St. James school had obtained an allocation of $\$ 1740$. Rev. Chalmers had reported that there were twenty students which included a few females had studied in that school. (Seymour, 1939)

While during Charles Brooke's rule, he had displayed a much clearer education policy compared to during James Brooke's rule which was seen as open. This could be seen with the existence of more government schools for Malay and Chinese children. However, the question of education for the Dayaks were still given to the Christian missionaries to handle. (Hammond, 1937). In his writing titled Queries, Charles Brooke had shown his stand and policy on education in Sarawak. The writings clearly shown that he didn't agree with the educational patterns as practised by the English and Dutch colonialists in South East Asia and Africa. He was of the opinion that the successful colonialists should be knowledgeable of the culture and languages of the natives. This policy had caused him to leave the question of education for the natives in the hands of private bodies such as the Christian missionaries and local leaders without giving any reasonable assistance.

The development of a comfortable missionary school was received by the non Muslim native population resulted in the emergence of another Christian missionary group in the form of The American Seventh Day Adventist (SDA). During the time of Vyner Brooke's rule, a 
grant of $\$ 2400$ was given to the SDA missionaries to open a missionary school. The entry of SDA missionaries began after sixteen Chinese in Kuching made an application to the SDA church in Singapore for missionaries to be sent to Sarawak in 1914. Then in 1922, the SDA missionaries began early education at Gartak Street in Kuching with the opening of their first school named Tsen Kwong School. However in 1925, the school's name was changed to Sunny Hill School. The increase in the number of students which consisted of Chinese, Iban and Malays and the capability to upgrade the school proved that the Christian propagation movement was able to bring development to the early education in Sarawak during the Brooke Dynasty rule. Other than that, the existence of SDA missionary school Ayer Manis located in the rural area along the Kuching-Serian road and which was build using financial allocation by the Chinese had provided lots of opportunities to the Bidayuh community in Serian district to learn agricultural skills training and getting available secular education. (Seymour, 1939)

In general, we could see that the development of education during the Brooke Dynasty was very slow and not very exciting. This was similarly in Malaya too under the British colonial rule. This could've been due to the policy of solely depending on the efforts and contributions by the Christian missionaries. In addition, the local population too depended very much on their own traditional beliefs and this made difficult any changes from their old beliefs to a new belief ie. the Christian religion. The effect from it was that they also received secular education from the colonialists.

\section{The History and Development Of Education in Sarawak During the British Administration.}

The 17 years of British administration began in Sarawak from 1946 to 1963 saw many changes in every aspects of the local populations life including in the educational aspect. The Cession of Sarawak to the British Colonial Government which turned it into a Crown Colony from 1 July 1946 saw the rehabilitation of schools under the British Military Administration (BMA). Later, the responsibility to rehabilitate schools was continued by the British Colonial Government with big changes made ie. the expanding of preaching activities and the provision of educational facilities after the War in rural areas which mainly made up of non Muslim native population (Idrus, 1990) In fact up until 1947, the number of English missionary schools had increased in their numbers and they were mainly located in the rural areas. (Idrus, 1990) Until the year 1963, there was a total of 67 secondary schools which provided educational facilities for the local children as a result from the efforts of missionary bodies and individuals apart from the government. (Sarawak Education Department Annual Summary, 1963).

The British and the missionaries had began their effort to reopen schools that were interrupted in their development due to the war. The results from this intervention by other parties such as the missionaries and the demands of the public for education, the British were involved in providing educational facilities to the public in Sarawak. By the end of 1946, there was a total of 73 government schools, 30 missionary schools, three private schools and 173 Chinese schools to provide educational facilities for the people in Sarawak. (Annual Report of Sarawak, 1947). In the early 1950s, the colonial government together with the Christian missionaries made an effort to establish primary schools at a few Bidayuh settlement districts. The British claimed this was for preparing the people for eventual independence. This was due 
to the British Colonialists wanting the Sarawak native people to be educated and are able to administer their own country (Minos, 2000). Therefore it's clear that the increase in the missionary schools during the British colonial administration together with the positive roles played by the missionaries had successfully increased the literacy rates among the people of Sarawak (Ooi, 1996). During the British colonial era, there were many missionary schools established to provide education for the Sarawak native people. The Anglican Christian denomination were among the active mission in propagating Christianity besides providing educational facilities for the local population. In 1957, the Anglican mission at Kampung Panchor had also established Anglican All Saint School and subsequently the primary school at Kampung Rituh Mawang in 1961 (Chang, 2004).

After the Japanese invasion era, the awareness among parents towards the importance of education for their children further increased. In fact, the attendance of pupils in primary and secondary schools increased every year between 1946 to 1963. (Chang, 2004). The increase in the number of schools were also the result of vigorous effort by the missionaries in their preaching of Christianity while taking care of the Sarawak people's welfare. The impact from the missionaries effort brought educational development not only to the urban areas but also to the rural areas in Sarawak. Until today, the former missionary schools are still being used even though the management of these schools are now taken over by the Sarawak Government.

\section{Conclusion}

The history of education in Sarawak had gone through three distinct era of rule namely The Brooke Dynasty era, The Japanese Occupation era and The British Colonial era. The educational policies of the three eras gave huge impact towards the development of missionary schools specifically in their mission of greatness in Sarawak. The open policy adopted from the early administration period opened up a large space for the missionaries with their religious mission resulting in the developing of structured and systematic missionary schools. In fact during the British Colonial Administration, the development of missionary schools continued to be a priority in bringing humanitarian mission for the local people. The glorious history of the missionary schools can be taken as the best benchmark for today's local national schools in order to dignify the quality of education either in their aspect of administration and the efficiency in their financial management. Thus, it's hope that each and every party would give their full support regardless of race or religion to always work together to increase the quality of education in Sarawak through thoughts, work ethics and quality management similar to the effort done and achieved by the missionary schools.

\section{References}

\section{Primary Source}

Annual Report on Sarawak for the year 1947. (1948). Kuching: Printed at The Government Printing

Office

Sarawak Education Department Annual Summary For 1963. Table 1A. In C.0. 802/22.

Sarawak Gazette. (1970). Vol.XCVI (1339)

Sarawak Gazette. (1970). Vol. XCVI (1348)

Sarawak Meseum Journal, Vol.XVI (32-33) 
INTERNATIONAL JOURNAL OF ACADEMIC RESEARCH IN PROGRESSIVE EDUCATION AND

DEVELOPMENT

Vol. 10, No. 3, 2021, E-ISSN: 2226-6348 @ 2021 HRMARS

\section{Books and Journals}

Ahmad, S. I., \& Santhiram, R. (1990). Perkembangan Pendidikan di Sarawak. Kuala Lumpur: Dewan Bahasa dan Pustaka.

Chang, F. F. (2004). History of Serian Bidayuh in Samarahan Division Sarawak. Kuching: The Sarawak Press Sdn. Bhd.

Cleophas, C. (1976). Sejarah Perkembangan Sosio-ekonomi Masyarakat Bidayuh. Latihan IImiah. Kuala Lumpur: Universiti Malaya.

Currey, L. E. (1933). Borneo. SPG handbooks: Westmint.

Hammond, R. W. (1937). Report Education in Sarawak, Typescript tersimpan di Arkib Muzium Sarawak.

Minos, P. (2000). The Future of the Dayak Bidayuhs in Malaysia, Kuching: Lynch Media \& Service.

Ooi, K. G. (1996). World Beyond the Rivers: Education in Sarawak from Brooke Rule to Colonial Office Administration 1841-1963. England: University of Hull.

Osman, S. (1972). Keadaan masyarakat Bumiputera Sarawak pada abad kelapan belas dan awal abad kesembilan belas: Satu tinjauan sejarah. Malaysia in History, 17(2).

Osman, S. (1990). Perkembangan Pelajaran Bumiputera Sarawak 1841-1941. Kuala Lumpur: Dewan Bahasa dan Pustaka.

Porritt, V. L. (1997). British Colonial Rule in Sarawak, 1946-1963. Kuala Lumpur: Oxford University Press.

Pringle, R. (1970). Rajahs and Rebels: The Iban of Sarawak under Brooke Rule, 1841-1941. London.

Runciman, S. (1960). The White Rajahs: A History of Sarawak from 1840 to 1946. London: Cambridge

Saint, M. (1992). Twenty Years in Sarawak 1848-68: A Flourish for the Bishop and Brooke's Friend Grant. Kuala Lumpur: S.Abdul Majeed \& Co.

Saunders, G. (1992). Bishops and Brookes: The Anglican Mission and the Brooke Raj in Sarawak 1841-1941. New York: Oxford University Press.

Varney, P. D. (1968). The Anglican Church in Sarawak from 1848 to 1852. Sarawak Meseum Journal, XVI, 32-33.

Varney, P. D. (1969). Iban Leaders. Sarawak Musuem Journal, XVIII, 34-35 